\title{
ARQUEOLOGIA DA GENEROSIDADE
}

Katia Teonia Costa de Azevedo ${ }^{1}$

$\mathrm{Na}$ ocasião em que atuei, com muito entusiasmo, como professora substituta no setor de latim entre os anos de 2006 a 2008, tive a companhia assídua do querido professor Pedro Paulo Funari, ao ministrar a disciplina Matrizes clássicas, que havia sido recentemente implementada como disciplina obrigatória na grade curricular dos cursos de Letras da Universidade Federal Fluminense.

Em atenção à carga horária (60h compartilhadas com o setor de grego), fui em busca de um material que pudesse introduzir brevemente os alunos no universo greco-romano, decidindo, pois, pelo livro Grécia e Roma (2002) de autoria de Pedro Paulo Abreu Funari. A abordagem introdutória e concisa da obra foi determinante para adoção do livro na bibliografia básica da referida disciplina, oferecida, no primeiro período, a alunos de inúmeras habilitações do curso de Letras (exceto para o curso de Latim) daquela instituição, estudantes que, em grande parte, experimentavam, naquela disciplina, seu primeiro contato formal com a cultura greco-romana.

Nesse sentido, me acompanhou durante esse período a presença imortalizada do professor Funari pela sua obra Grécia e Roma (2002), uma singela publicação da coleção Repensando a História, coordenada por Jaime Pinsky. Obra que oferece uma perspectiva globalizada de aspectos da vida pública e privada, cultura, pensamento, mitologia, amor e sexualidade, como esclarece o subtítulo do livro.

O professor Funari foi, portanto, o nosso guia nessa prazerosa e enriquecedora viagem à antiguidade clássica, uma jornada conduzida pela clareza de palavras que traduzem um didatismo evidenciado não apenas em sua linguagem, bem como na apresentação e seleção dos temas debatidos na obra. Um tratamento que se complementa com o uso de fontes primárias de natureza material e escrita, propiciando um enriquecimento no tratamento de alguns dos aspectos apresentados, como por exemplo, a posição da mulher na sociedade grega e romana (Funari, 2002: 55, 104-106). O emprego de documentos escritos

\footnotetext{
1 Professora Doutora, Universidade Federal do Rio de Janeiro, Rio de Janeiro, Brasil. E-mail: katiateonia@letras.ufrj.br
} 
possibilitou antecipar o contato com autores representativos da literatura latina, tais como Catulo e Ovídio (Funari, 2002: 106), poetas estudados em momento posterior do curso. São oferecidos ainda, ao final do livro, uma linha do tempo para auxiliar na contextualização e uma seleção bibliográfica que complementa o conteúdo apresentado, elementos que se coadunam com a natureza didática e introdutória do livro Grécia e Roma.

O convite para participar do Seminário de Letras Clássicas em 2007, no Instituto de Letras da Universidade Federal Fluminense, em que o professor Funari proferiu a conferência As inscrições latinas e o estudo da sociedade romana, foi a feliz ocasião em que pude conhecê-lo pessoalmente e relatar sobre a profícua experiência que tinha em sala de aula com o uso do seu livro. Esse foi também o momento em que pude perceber a sua imensa generosidade e cordialidade, virtudes reconhecidas em sua escuta e na disposição de oferecer prontamente outros materiais de sua autoria que poderiam ser proveitosos em meu curso (e foram!).

Essas breves palavras são a expressão sincera da minha gratidão e admiração ao querido professor Pedro Paulo Abreu Funari. Parabenizo pela notável iniciativa e agradeço imenso ao professor Glaydson José da Silva pela oportunidade tão especial de tornar público o meu afeto àquele que nos une hoje nessa benemérita edição laudativa. 